\title{
Metadiscourse Markers of Online Texts: English and Persian Online Headlines Use of Metadiscourse Markers
}

\author{
Akram Yazdani \\ English Department, Faculty of Humanities, Najafabad Branch, Islamic Azad University, Najafabad, Isfahan, Iran \\ Hadi Salehi (Corresponding author) \\ English Department, Faculty of Humanities, Najafabad Branch, Islamic Azad University, Najafabad, Isfahan, Iran \\ E-mail: hadisalehi1358@yahoo.com
}

Received: 15-06-2016

Accepted: 24-07-2016

Published: 31-07-2016

doi:10.7575/aiac.ijels.v.4n.3p.41

URL: http://dx.doi.org/10.7575/aiac.ijels.v.4n.3p.41

\begin{abstract}
The aim of the present study was to illuminate the differences between Persian and English in online headlines in terms of applying metadiscourse markers in the first two months of the year 2015. To fulfill this purpose, 100 Persian and English online headlines (each 50 headlines) were chosen randomly from English and Persian newscasts such as VOA, CNN, Bistosi (20:30), and Bashgahkhabarnegaran. The specific research areas of interest was whether online Persian and English headlines differed in making use of metadiscourse markers. The corpus was recorded and divided in two groups of Persian online headlines and English online headlines. According to Hyland's (2005) model, interactive and interactional metadiscourse markers were identified in online headlines. Corpus analysis showed that according to descriptive statistics, Persian and English were not significantly different in using metadiscourse markers in online headlines. The findings can help to keep journalism students aware of this aspect of metadiscourse.
\end{abstract}

Keywords: Metadiscourse, English headlines, Persian headlines, Field-specific

\section{Introduction}

From a social perspective, writing involves interaction between writers and readers. These two groups "negotiate their meanings, and use interpersonal resources to organize texts coherently and convey their personality, credibility, reader sensitivity and relationship to the message"(Hyland, 2005). The social view of written communication suggests that the text is a site where the writer and the reader are engaged in dialogic interaction based on shared interpretive practices. Hyland (2005) argued that the writing is not neutral but it reflects the perspectives and values of the two engaging parties.

Metadiscourse is a primary means that enables the author to accomplish this. It involves writers and their readers in mutual acts of comprehension and involvement(Hyland, 2005). Writers use metadiscourse to direct their readers and display an appropriate professional persona in order to persuade their readers, as such metadiscourse is an important feature of persuasive writing ( Hyland, 1998).

In a piece of writing, metadiscourse is those textual aspects that organize the discourse explicitly; they engage the audience and communicate the attitude of the writer. It is by the help of metadiscourse that the text brings the writer close to the reader in that it shows that the writer is aware of the reader and his needs - any explanation, guidance, ... (Rezaeizadeh, Baharlooei \& Simin, 2015; Simin \& Tavangar, 2009; Tavakoli et al. 2012). When the writer is concerned about the interpretations of the reader, he uses metadiscourse. Metadiscourse is not related to the content, but the local requirements of textual communication in a particular context. We use metadiscourse when we filter our ideas through a concern with how our readers will take them. Though metadiscourse does not refer to what we are primarily saying about our subject, we need some metadiscourse in everything we write. Metadiscourse is generally used to announce what writers will do to list the parts or steps in the presentation, to express logical connection, to show the degree of writers' certainty, or to indicate their intentions.

According to the above, it would be helpful to study the role of metadiscourse in the relation between writer, reader, and text. Since mass media are believed to be a means of discourse exchange, the focus of this study is on the use of metadiscourse in online English and Persian newspaper headlines. The reason for investigating online newspaper headlines is that most of the previous studies were concerned with metadiscourse in educational fields, such as English as Second Language and English as Foreign Language teaching, while media, though important, have not received much attention. This study generally aimed to conduct a comparative analysis of metadiscourse markers in online headlines written by English and Iranian journalists. The specific objective of this study is as below: 
- To determine significant difference between online English and Persian headlines in terms of using metadiscourse markers.

\section{Literature Review}

Metadiscourse, a widely used and discussed concept in current discourse analysis and applied linguistics studies, is an attempt to capture the interactions between text producers and the text and between text producers and the imagined audience. According to Williams(1981), metadiscourse markers come into play when we are concerned with how our reader will take our ideas. Metadiscourse does not depend on what we intend to say, however, we need some metadiscourse in everything we write. In addition, he asserts that metadiscourse is present wherever writers explicitly refer to their own act of thinking, or readers act of reading, or even writing organization. Metadiscourse is used to help explain essays, to guide reader response or to structure text as a whole.

A terminologically similar, yet conceptually different, area to metadiscourse markers in discourse analysis is discourse markers. It is mostly studied as markers signaling coherence relations (Taboada, 2006). It is studied under the headings of coherence markers, lexical markers, discourse operators, discourse connectives, clue phrases, clue words and discourse signaling devices (Taboada, 2006). Fraser (1999) proposed that discourse markers are conjunctions, adverbs, and propositional phrases that connect two sentences or clauses together. Redeker (1991) suggested that discourse markers link not only contiguous sentences, but a sentence with its immediate context. Schiffrin (2001) believes that discourse markers can have global functions in addition to local ones (i.e. connecting propositional meaning or determining the structure of the exchange in conversation). Unlike Fraser, he included items like oh, you know, I mean, as discourse markers.

Contrasting with discourse markers is metadiscourse: the linguistic tools that help the writer to refer to his own thinking and writing as he thinks and writes (e.g., to sum up, I believe, frankly); to the structure of the text (e.g., first, finally, therefore); and even to the reader's act of reading (e.g., note that, consider now, however).

Metadiscourse studies can be found in almost all kinds of communication among members of differing communities. Casual conversation Deborah Schiffrin (1980) school textbooks (Crismore, 1989) oral narratives (Norrick, 2001), (Farnsworth, 1990), undergraduate textbooks (Hyland, 2000), postgraduate dissertations (Bunton, 1999; Hyland, 2004; Swales, 1990), company annual reports (Hyland, 1998) are among the areas that have been studied with regard to the use of metadiscourse.

As claimed by Hyland (2005), Zelling Harris first used the term metadiscourse in 1959 to represent the attempt made by a writer or a speaker to guide the receiver. Williams (1981), Crismore (1989), Kopple (1985), and mostly Hyland (during the past fifteen years) and some other scholars further developed this concept. However, Adel (2006, pp.167179) has recently contrasted this broad approach with a narrow approach and taking side with the latter; she has excluded intertextual reference (following Mauranen, 1993) and stance from the framework of metadiscourse. All in all, metadiscourse means that in communication, language is not only used to convey information and knowledge; it is also used for any efforts regarding text organization, feelings, references to participants, etc.

In his proposed model, Hyland (2005) assumed two main categories for metadiscourse: interactive and interactional. Thompson and Thetela (1995) had made such a distinction earlier, so that to show that interaction has two distinctive features: organizational and evaluative (Table 1). The model has drawn upon several earlier models.

Table 1. Interpersonal Model of Metadiscourse (Hyland, 2005)

\begin{tabular}{|c|c|c|}
\hline Category & Function & Examples \\
\hline 1. Interactive & Help to guide the reader through the text & Resources \\
\hline 2. Transitions & Express relation between main clauses & In addition; but; thus; and \\
\hline 3. Frame markers & Refers to discourse acts, sequences, or stages & Finally, to conclude, my purpose is \\
\hline 4. Endophoric markers & Refer to information in other parts of the text & Noted above, see figure, in section 2 \\
\hline 5. Evidential & Refer to information from other text & According to $\mathrm{X}, \mathrm{Z}$ states \\
\hline 6. Code glosses & Elaborate propositional meanings & Namely, e.g., such as, in other words \\
\hline 7. Interactional & Involve the reader in the text & Resources \\
\hline 8. Boosters & Emphasize certainty or close dialogue & About, in fact, definitely, it is clear that \\
\hline 9. Attitude markers & Express writers attitude to proposition & Unfortunately, I agree, surprisingly \\
\hline 10. Self-mentions & Explicit reference to author & I, me, my, our \\
\hline 11. Hedges & Withhold commitment and open dialogue & Might, perhaps, possible \\
\hline 12. Engagement markers & Explicitly build relationship with readers & Consider, note, you can see that \\
\hline
\end{tabular}




\section{Method}

\subsection{Research Design}

The present study is a descriptive research which generally applies quantitative data collection method to conduct an indepth analysis of the usage of metadiscourse markers between Persian and English online headlines.

\subsection{Research Instrument and Materials}

In order to conduct this research and meet the objective, the following instruments and materials were used to collect the required data.

\subsubsection{Corpus}

We used a corpus of English and Persian data composed of 100 online headlines (50 written in English and 50 in Persian). The selected online English headlines were from VOA and CNN. Online Persian headlines were selected from Bistosi (20:30) and BashgahKhabarnegaran to increase homogeneity of our corpus. As in the case of other comparative and contrastive studies, ensuring the comparability of the two corpora of the study is important. Therefore, in order to meet this comparability requirement, online headlines in both groups were selected from diverse and different topics including social, political, economic, cultural, entertainment, sport, and world news.

\subsubsection{Hyland's (2005) Model}

We used a model of Hyland (2005) to analyze interactive and interactional metadiscourse markers of 50 English online headlines and 50 Persian online headlines, in order to disclose the differences between these headlines regarding the use of interactive and interactional metadiscourse markers.

\subsection{Procedures}

\subsubsection{Data Collection Procedure}

The data collection for our research was consisted of retrieving a large portion of headlines from the electronic version of elite and influential English and Persian headlines in the United States and Iran through the internet. Due to the research aim, it was determined that there had to be several newscasts serving as the database for the study. In more precise terms, the headlines of different newscasts were quite diverse in their styles or textual strategies (Fowler, 1991; Shams, 2005); therefore, in order to reduce stylistic influence of journalists and newscasts in the analysis, an extended scope of data -4 newscasts( 2 in English and 2 in Persian) were selected. English newscasts include of VOA and CNN. Persian newscasts are Bistosi (20:30) and Bashgahkhabarnegaran.

In order to ensure that diachronic changes would not affect the selected online headlines, only headlines published in the period between the first two months of the year 2015(January and February) were included in the sample. In this study, regarding the first question, 100 online headlines, 50 in English and 50 in Persian were culled from the selected online headlines for a close contrastive analysis.

\subsubsection{Data Analysis Procedure}

After retrieving a large portion of headlines from newscasts (2 in English and 2 in Persian) and selecting the headlines which compose the corpus of the study. In order to extract the frequency of interactive and interactional metadiscourse markers based on Hyland's model (2005), we read online headlines carefully and word by word, and counted the markers manually. All the data were analyzed twice, to prevent any counting errors. The data were also evaluated by a master student of English Teaching and a university lecturer, both experts in the field and knowledgeable about interactive and interactional metadiscourse markers based on Hyland's (2005) model. Frequencies of these metadiscourse markers were compared between English and Persian online headlines.

\section{Results}

Concerning the descriptive statistic of research, the findings show that as for interactive metadiscourse markers, transition greatly differed from Persian $(f=14)$ to English $(f=2)$; no instances of frame markers, and endophoric markers. Finally, the frequency of use of code glosses in both Persian and English headlines was the same $(f=2)$. Regarding interactional metadiscourse markers, the biggest difference between Persian ( $f=20)$ and English $(f=14)$ was that of attitude markers; the other categories of interactional discourse markers (i.e. hedges, boosters, self-mentions, and engagement markers) did not differ substantially from Persian to English. It indicates that the difference between the frequencies of interactional metadiscourse markers used by online Persian and English headlines was not statistically significant. The frequencies of use of most types of metadiscourse markers were roughly similar (except for transitions and attitude markers), and this resulted in the lack of statistical difference between Persian and English online headlines with respect to different types of metadiscourse markers they contained. 
Table 2. Frequencies of Metadiscourse Markers of Different Types Used in Persian and English Headlines

\begin{tabular}{l|lccc}
\hline \multicolumn{2}{c}{ Metadiscourse Markers } & Persian & English & Total \\
\hline \multirow{3}{*}{ Interactive } & Transition & 14 & 2 & 16 \\
& Frame Markers & 0 & 0 & 0 \\
& Endophoric Markers & 0 & 0 & 0 \\
& Code Glosses & 2 & 2 & 4 \\
\hline \multirow{5}{*}{ Interactional } & Hedges & 12 & 11 & 23 \\
& Boosters & 2 & 0 & 34 \\
& Attitude Markers & 20 & 14 & 7 \\
& Self-Mentions & 2 & 5 & 5 \\
\hline \multirow{5}{*}{} & Engagement Markers & 2 & 3 & 91 \\
\hline
\end{tabular}

As it could be seen in Table 3, among interactive markers of Persian online headlines, the highest percentage belongs to transition markers $(25.92 \%)$ and the lowest percentage relates to frame markers and endophoric markers $(0 \%)$. Among interactional markers, the highest percentage belongs to attitude markers $(37.03 \%)$ and the lowest percentages relates to boosters, self-mentions, and engagement markers (2\%). In sum, it can be concluded that interactional with $70.33 \%$ are used more than interactive markers with $29.62 \%$. Table 4.3 shows the result of descriptive analysis of English online headlines regarding the use of different types of metadiscourse markers.

Table 3. Descriptive Statistics of Metadiscourse Markers of Different Types in Persian Headlines.

\begin{tabular}{|c|c|c|c|}
\hline & & Frequency & Percentage \\
\hline \multirow{4}{*}{ Interactive markers } & Transition & 14 & 25.92 \\
\hline & Frame markers & 0 & 0 \\
\hline & Endophoric & 0 & 0 \\
\hline & Code glosses & 2 & 3.7 \\
\hline \multicolumn{2}{|l|}{ Sub-total } & 16 & 29.62 \\
\hline \multirow{5}{*}{ Interactional markers } & Hedges & 12 & 22.22 \\
\hline & Boosters & 2 & 3.7 \\
\hline & Attitude markers & 20 & 37.03 \\
\hline & Self-mentions & 2 & 3.7 \\
\hline & Engagement markers & 2 & 3.7 \\
\hline \multicolumn{2}{|l|}{ Sub-total } & 38 & 70.33 \\
\hline \multicolumn{2}{|l|}{ Total } & 54 & 100 \\
\hline
\end{tabular}

As it could be seen in Table 4, among interactive markers of English online headlines, the highest percentages belong to transition markers and code glosses $(5.40 \%)$ and the lowest percentages relate to frame markers and endophoric markers $(0 \%)$. Among interactive markers, highest percentage belongs to attitude markers $(37.83 \%)$ and the lowest percentage relates to boosters $(0 \%)$. Generally, interactional markers with $89.16 \%$ were applied more than interactive ones with $10.8 \%$.

Table 4. Descriptive Statistics of Metadiscourse Markers of Different Types in English Headlines.

\begin{tabular}{|c|c|c|c|}
\hline & & Frequency & Percentage \\
\hline Interactive markers & $\begin{array}{l}\text { Transition } \\
\text { Frame markers } \\
\text { Endophoric } \\
\text { Code glosses }\end{array}$ & $\begin{array}{l}2 \\
0 \\
0 \\
2 \\
\end{array}$ & $\begin{array}{c}5.40 \\
0 \\
0 \\
5.40 \\
\end{array}$ \\
\hline Sub-total & & 4 & 10.8 \\
\hline Interactional markers & $\begin{array}{l}\text { Hedges } \\
\text { Boosters } \\
\text { Attitude markers } \\
\text { Self-mentions } \\
\text { Engagement markers }\end{array}$ & $\begin{array}{c}11 \\
0 \\
14 \\
5 \\
3 \\
\end{array}$ & $\begin{array}{c}29.72 \\
0 \\
37.83 \\
13.51 \\
8.10 \\
\end{array}$ \\
\hline \multicolumn{2}{|l|}{ Sub-total } & 33 & 89.16 \\
\hline Total & & 37 & 100 \\
\hline
\end{tabular}


Concerning the descriptive statistics of the findings indicated that interactional markers $(78.02 \%)$ were employed more than interactive ones $(21.97 \%)$. Interactional markers were Persian online headlines $(70.33 \%)$ comparing to English online headlines (89.16\%). Among interactive markers, in Persian online headlines, transitions (25.92\%) were applied more than other interactive markers such as frame markers, endophoric markers, and code glosses. Among interactional markers, in Persian online headline, attitude markers (37.03\%) were applied more than other interactional markers such as hedges, boosters, self-mentions, and engagement markers. Among interactive markers, in English online headlines, transitions andcode glosses $(5.40 \%)$ were applied as the most proportion. Among interactional markers, in English online headlines, attitude markers $(37.83 \%)$ were applied as the most proportion.

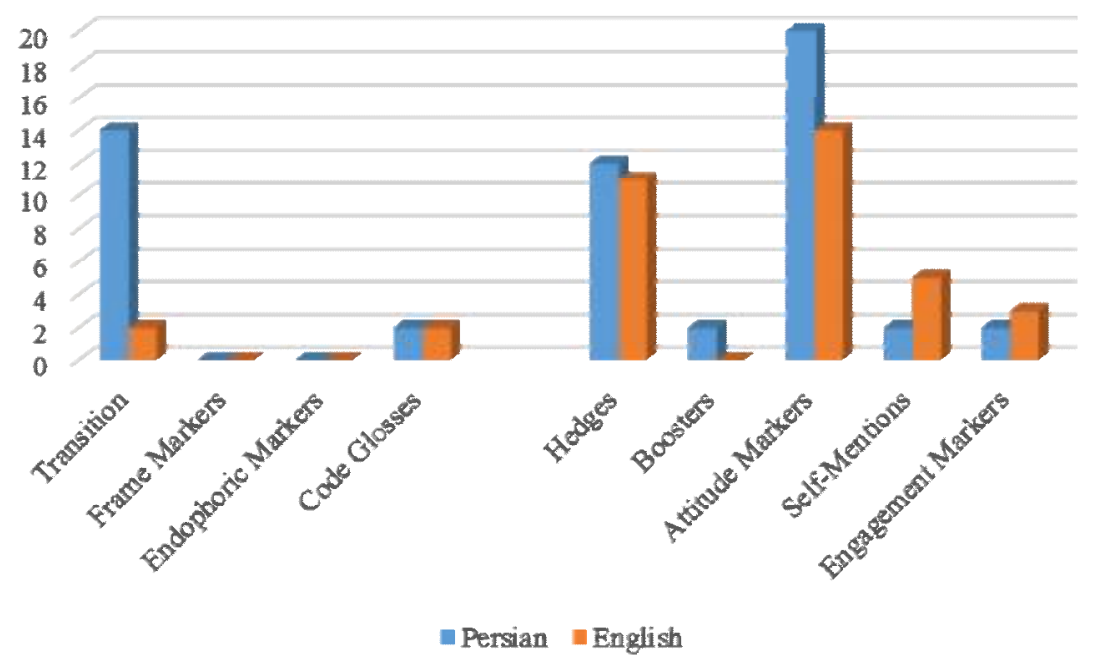

Figure1. Metadiscourse Markers Frequencies in Persian and English Headlines

As it could be seen in Figure 1, the frequencies of use of most types of metadiscourse markers were roughly similar (except for transitions and attitude markers), and this resulted in the lack of statistical difference between Persian and English online headlines with respect to different types of metadiscourse markers they contained.

\section{Discussion and Conclusion}

With regard to the research, conclusion were made that there is not any significant difference between English and Persian online headlines in terms of using metadiscourse markers. Concerning the descriptive statistic of research, the findings show that regarding the use of interactive metadiscourse markers in online headlines, the biggest difference between Persian $(f=20)$ and English $(f=14)$ was that of attitude markers; the other categories of interactional discourse markers (i.e. hedges, boosters, self-mentions, and engagement markers) did not differ substantially from Persian to English. It indicates that the difference between the frequencies of interactive metadiscourse markers used by online Persian and English headlines was not statistically significant. It could be inferred that the difference between the frequencies of interactional metadiscourse markers used by online Persian and English headlines did not appear to reach statistical significance. As it could be seen in Figure.1, the frequencies of use of most types of metadiscourse markers were roughly similar (except for transitions and attitude markers),

Concerning the descriptive statistics of research question one, the findings indicated that, interactional markers $(78.02 \%)$ were employed more than interactive ones $(21.97 \%)$. Interactional markers were used as least proportion in Persian online headlines $(70.33 \%)$ comparing to English online headlines $(89.16 \%)$. Among interactive markers, in Persian online headlines, transitions $(25.92 \%)$ were applied more than other interactive markers such as endophoric markers, frame markers and code glosses, while among interactional markers, attitude markers (37.03\%) were applied more than other interactional markers such as boosters, hedges, self-mentions, and engagement markers. Among interactive markers, in English online headlines, transitions andcode glosses were (5.40\%). Among interactional markers, in English online headlines, attitude markers (37.83\%) were applied as the most proportion.

Concerning the distribution of interactive and interactional metadiscourse markers, interactional markers were employed more than interactive ones in Persian and English online headlines. But, interactional markers were used as most proportion in Persian online headlines (41.57\%) comparing to English online headlines (36.26\%).Finally, according to descriptive analysis, no significant difference is observable between English and Persian online headlines regarding metadiscourse markers. It is hoped that the results of this study give significant insights into the teaching of English as a foreign language in general and the teaching of writing in English in particular. The results of the study are beneficial for EFL students and their teachers in analyzing, understanding, and correcting their intercultural linguistic problems in writing. Teachers can encourage students to apply these metadiscourse markers appropriately. The findings 
of the study are also beneficial for translation area (both for teachers and students in translation courses and professional translators). It is also practical to train journalism students about using metadiscourse markers appropriately in order to achieve more success in reporting the world events.

\section{References}

Adel, A. (2006). Metadiscourse in L1 and L2 English (Vol. 24). John Benjamins Publishing.

Bunton, D. (1999). The use of higher level metatext in Ph. D theses. English for Specific Purposes, 18, S41-S56.

Crismore, A. (1989). Talking With Readers: Metadiscourse As Rhetorical Act. Lang. Retrieved from https://books.google.com/books?id=BXsFAQAAIAAJ

Farnsworth, R. (1990). How the other half sounds: An historical survey of musical rhetoric during the baroque and after. Rhetoric Society Quarterly, 20(3), 207-224.

Fowler, R. (1991). Language in the News: Discourse and Ideology in the Press. Taylor \& Francis. Retrieved from https://books.google.com/books?id=bX5GAQAAQBAJ

Fraser, B. (1999). What are discourse markers? Journal of Pragmatics, 31(7), 931-952.

Hyland, K. (1998). Persuasion and context: The pragmatics of academic metadiscourse. Journal of Pragmatics, 30(4), 437-455.

Hyland, K. (2000). Disciplinary Discourses: Social Interactions in Academic Writing. Stationery Office. Retrieved from https://books.google.com/books?id=6rKpPwAACAAJ

Hyland, K. (2004). Disciplinary interactions: Metadiscourse in L2 postgraduate writing. Journal of Second Language Writing, 13(2), 133-151.

Hyland, K. (2005). Metadiscourse: Exploring Interaction in Writing. Bloomsbury Academic. Retrieved from https://books.google.com/books?id=kyztT1czUfMC

Kopple, V. (1985). William J. Some explanatory discourse on metadiscourse. College Composition and Communication, 36.

Mauranen, A. (1993). Contrastive ESP rhetoric: Metatext in Finnish-English economics texts. English for Specific Purposes, 12(1), 3-22.

Norrick, N. R. (2001). Discourse markers in oral narrative. Journal of Pragmatics, 33(6), 849-878.

Redeker, G. (1991). Linguistic markers of discourse structure. Linguistics, 29(6), 1139-1172.

Rezaeizadeh, Z., Baharlooei, R. \& Simin, S. (2015). Gender-Based Study of Interactive and Interactional Metadiscourse Markers in Conclusion Sections of English Master Theses.International Letters of Social and Humanistic Sciences, 47. 195-208.

Schiffrin, D. (1980). Meta-talk: Organizational and evaluative brackets in discourse. Sociological Inquiry, 50(3-4), 199236.

Schiffrin, D. (2001). Discourse markers: language, meaning, and context. The Handbook of Discourse Analysis, 1, 5475.

Shams, M. R. (2005). Reading English Newspapers. Jungle Publication Tehran.

Simin, S., \& Tavangar, M. (2009). Metadiscourse knowledge and use in Iranian EFL writing. The Asian EFL Journal Quarterly, 11(230).

Swales, J. (1990). Genre analysis: English in academic and research settings. Cambridge University Press.

Taboada, M. (2006). Discourse markers as signals (or not) of rhetorical relations. Journal Pragmatics, 38(4), 567-592.

Tavakoli, M., Bahrami, L., \& Amirian, Z. (2012). Improvement of Metadiscourse Use among Iranian EFL Learners through a Process-based Writing Course. Journal of English Language Teaching and Learning, 4(9), $129-164$.

Thompson, G., \& Thetela, P. (1995). The sound of one hand clapping: The management of interaction in written discourse. Text-Interdisciplinary Journal for the Study of Discourse, 15(1), 103-128.

Williams, J. M. (1981). Ten lessons in clarity and grace. University of Chicago Press, Chicago. 